\title{
IES
}

\section{THE ABOLITION OF THE EARNINGS RULE FOR UK PENSIONERS}

Richard Disney Sarah Tanner 


\title{
THE ABOLITION OF THE EARNINGS RULE
}

\section{FOR UK PENSIONERS ${ }^{1}$}

\author{
Richard Disney \\ Sarah Tanner \\ University of Nottingham and IFS \\ Institute for Fiscal Studies
}

This version: April 2000

\section{Abstract}

The US has legislated to abolish its social security earnings test. A priori it is not possible to predict the effect this will have on work incentives. Using data from the Family Expenditure Survey we show that the abolition of the earnings rule in the UK increased the number of hours worked by men. The lack of any evidence of a reduction in hours may be a consequence of those who previously earned more than the earnings threshold deferring pension receipt at an actuarially favourable rate. This is consistent with there being little evidence of a significant change in the number of deferrals after the earnings rule was abolished.

\footnotetext{
${ }^{1}$ Funding for this research has been provided by the Economic and Social Research Centre for the Microeconomic Analysis of Fiscal Policy at the Institute for Fiscal Studies. Material from the Family Expenditure Survey made available by the Office for National Statistics through the ESRC data archive has been used by permission of the controller of ONS. The authors are grateful to seminar participants at IFS for useful comments.
} 


\section{Summary}

Before 1989 men aged 65-69 and women aged 60-64 earning above a certain threshold would have their state pension reduced. This 'earnings test' was abolished in October 1989 with the intention of encouraging employment. As other OECD countries consider a similar reform, this paper examines the impact on participation, hours and earnings in the UK.

A priori the effect on work incentives is ambiguous. Some workers who are currently earning at or near the earnings threshold are likely to increase their hours. But for other workers who currently defer their pension at an actuarially unfair rate, abolishing the earnings test will cause their lifetime wealth to increase, which could lead them to reduce the number of hours worked. The size of this wealth effect depends on whether or not the deferral rate is actuarially fair.

A simple differences in differences analysis is used to show that abolishing the earnings test had a positive effect on the hours and earnings of men, although the evidence for women is inconclusive. Among men there was an increase of between 3 -4 hours per week. To get some idea of the magnitude of this effect, an earnings response of this size would generate additional tax revenue for the government of around $£ 20$ million per year (in 1989 prices). The evidence suggests that the absence of a positive wealth effect working in the other direction is because the majority of those who previously chose to defer their pension continue to do so. 


\section{The abolition of the earnings rule for UK pensioners}

\section{Introduction}

Many OECD countries operate earnings tests which restrict the amount of pension that can be received by people who continue to work past the pensionable age (see Table 1). These tests often involve reductions in benefits at high effective withdrawal rates for those whose earnings exceed a certain threshold. At the same time, however, many countries permit individuals to defer receipt of their social security pension after the first age at which they are entitled to receive benefits. By so doing, individuals gain additional pension entitlements, although not always at an actuarially fair rate.

Table 1 Earnings Tests in OECD countries

\begin{tabular}{lll}
\hline & $\begin{array}{l}\text { Disregard } \\
\text { (\% of average earnings) }\end{array}$ & Withdrawal rate (\%) \\
\hline Deferral not possible & 160 & 15 \\
\hline Canada & 116 & full \\
Greece & 50 & 60 \\
Denmark & 30 & full \\
Austria & 33 & 100 \\
Belgium & 18 & 50 \\
Norway & 8 & 50 \\
Australia & None & full \\
Ireland & None & full \\
Portugal & None & full \\
Spain & & \\
Deferral possible & 23 & 100 \\
\hline Italy & $17-90 / 90$ & $20 /$ full \\
Japan & 38 & $33-50$ \\
United States & & \\
No restrictions & France & Germany \\
\hline Finland & New Zealand & Sweden \\
Netherlands & UK & \\
Switzerland & Portugal and Spain & \\
\hline Notes: Pension & &
\end{tabular}

Notes: Pension receipt in Ireland, Portugal and Spain conditional on withdrawal from work; France conditional on withdrawal from normal work. Pension withdrawn at a 100 per cent rate between 29 and 33 per cent of average earnings in Belgium. Italy gives a higher disregard for self-employment incomes (which are an important income source). Australia has a means-tested social security system. Source: Disney and Edward Whitehouse (1999). 
With the trend towards early retirement in many OECD countries there has been some debate as to whether abolishing these earnings tests can encourage participation among older workers. The US has recently legislated to abolish its social security earnings test with this aim. However, the effect on work incentives is a priori ambiguous. Some workers who are currently earning at or near the earnings threshold are likely to increase their hours. But for other workers who currently defer at an actuarially unfair rate, abolishing the earnings test will cause their lifetime wealth to increase, which could lead them to reduce the number of hours worked.

A number of US studies carried out a decade or so ago, summarised in John Gruber and Peter Orszag (1999), found little evidence of an impact on the earnings test on labour supply. More recently, Leora Friedberg (1997) has examined the impact of the test utilising the temporal variation in effective tax rates, age coverage and exemption limits as a 'natural experiment.' She found that the test had a significant adverse impact on hours worked by older men. For the UK, a study by Zabalza, Pissarides and Barton (1980) predicted an increase in hours as some men moved from part-time to full-time work.

The UK abolished its earnings rule in October 1989. This paper assesses the effects of abolition using the standard 'differences of differences' approach. It shows that the abolition of this earnings test led to an increase in hours worked by men over pension age, by about $3-4$ hours per week. The evidence suggests that the absence of a positive wealth effect working in the other direction is because the majority of those who previously chose to defer their pension continue to do so.

The structure of the paper is as follows. The next section gives details of the UK 
earnings rule and the rules for pension deferral. Section 3 provides a simple model of the individual's decisions whether to retire and whether to defer pension receipt. Section 4 contains evidence on the effect of the abolition of the earnings rule in the UK on hours and earnings. Section 5 concludes.

\section{State pensions and the earnings rule in the UK}

\section{The earnings rule}

Before October 1989 men aged 65-69 and women aged 60-64 could only receive the full basic state pension if they were 'retired'. This meant they were

1. Not working

2. Working, but with earnings (including tax but exclusive of work-related costs) less than or only occasionally greater than a specified limit.

3. Working but,

- only occasionally,

- to an 'inconsiderable extent' (normally less than 12 hours a week)

- in circumstances 'not inconsistent with retirement'. This referred to the lightness of duties, freedom from normal working hours, and other elderly people doing similar work. $^{2}$

Failure to meet any of these conditions would result in the individual's basic state pension being withdrawn. Initially the rate of withdrawal was 50 per cent for earnings falling between a specified lower and upper earnings limit. For earnings above the 
upper limit, however, the rate of withdrawal increased to 100 per cent. The upper and lower limits that operated between 1984 and 1989, together with the rates of the basic state pension, are summarised in Table 2.

Table 2 Basic state pension and earnings rule limits (£ per week)

\begin{tabular}{|l|l|l|l|}
\hline Year & Basic & Earnings rule & Earnings rule \\
& state pension & lower limit & upper limit \\
\hline $1984-85$ & $£ 34.69$ & $£ 65$ & $£ 69$ \\
$1985-86$ & $£ 36.71$ & $£ 70$ & $£ 74$ \\
$1986-87$ & $£ 38.57$ & $£ 75$ & $£ 79$ \\
$1987-88$ & $£ 39.50$ & $£ 75$ & $£ 79$ \\
$1988-89$ & $£ 41.15$ & $£ 75$ & $£ 79$ \\
1989 & $£ 43.60$ & $£ 75$ & $£ 79$ \\
\hline
\end{tabular}

\section{Deferral}

At the time the earnings test was in operation, anyone could choose to defer receipt of the basic state pension for up to five years at a rate of 7.5 per cent for each year that they deferred. This rate would be actuarially fair for someone expecting to live 14.3 years beyond the state pension age (assuming no discounting). In fact the life expectancy for a man aged 65 is 14.267 years (based on the mortality experience of England and Wales 1990-1992), making deferral roughly actuarially fair for an average male, assuming that they do not discount the future. For a woman life expectancy at 60 is 22.079 years. The combination of longer life expectancy and an earlier state pension age makes deferral actuarially favourable for an average female, so long as her discount rate is greater than 0.956 . It is worth pointing out that since a married woman without a pension in her own right inherits her husband's basic state

\footnotetext{
${ }^{2}$ See Richard Smith and Mark Rowland (1986)
} 
pension after he is dead, deferral could be actuarially fair for the couple, if not for the husband. $^{3}$

\section{Modelling retirement and deferral decisions}

What were the options facing a worker when the earnings rule operated? To analyse the problem, consider a simple two-period model. In the first period the individual decides whether to (continue to) work and whether to receive a flat pension - yielding three possible options. He can retire immediately and start drawing his pension. He can carry on working and defer pension receipt or he can carry on working and start drawing his pension, in which case he is subject to an earnings rule. ${ }^{4}$ In the second period, the individual is retired and receives a flat-rate pension, the value of which depends on the choice made in the first period.

Assume a general utility function;

$$
U=U\left(Y, L_{w} \mid \theta\right) \quad U_{Y}>0, U_{L}>0
$$

where $Y$ is total income in both periods, $L_{w}$ is leisure (which depends on earnings, $w$, in the first period), and $\theta$ is the (individual-specific) probability of surviving until the second period.

\footnotetext{
${ }^{3}$ Before 1978 married women could opt to pay a reduced rate of National Insurance which meant they did not qualify for a basic state pension in their own right, but couples in which one partner does not qualify would receive a dependant's addition.

${ }^{4}$ We ignore the fourth possible option - retire and defer pension receipt - by assuming no other available source of income.
} 
If the individual retires immediately his total income is given by;

(1) $\quad Y=p+\theta \beta p$

where $p$ is the flat-rate pension and $\beta$ is the discount rate.

If he decides to continue to work and defer pension receipt, his income is given by;

$$
Y=w(1-t)+\theta \beta p(1+r)
$$

where $r$ is the adjustment of the pension arising from deferral and $t$ is the average rate of tax which is payable when the individual is working but not when they are retired. ${ }^{5}$

If he works, but does not defer pension receipt his total income is;

$$
\begin{aligned}
& Y=w^{*}+\theta \beta p \text { where } \\
& \text { (3i) } w^{*}=(w+p)(1-t) \text { if } w<w_{0} \\
& \text { (3ii) } w^{*}=\left(w+p\left(1-w+w_{0}\right)\right)(1-t) \text { if } w_{0} \leq w<w_{0}+p \\
& \text { (3iii) } w^{*}=w(1-t) \text { if } w \geq w_{0}+p
\end{aligned}
$$

where the non-linearity in the wage outcome reflects the operation of the earnings rule. ${ }^{6}$

Faced with these different possibilities for total income, what would an individual choose to do? Certain options can be eliminated fairly easily. For example, the

\footnotetext{
${ }^{5}$ Pension income is assumed not to be taxed since, in the UK, the value of the individual's personal tax allowance is greater than the value of the basic state pension.

${ }^{6}$ For simplicity, we ignore the 50 per cent withdrawal rate.
} 
individual would always choose 3(i) over 3(ii) since $\partial w^{*} / \partial w=0$ but we might expect to see a 'bunching' of individuals at the kink point $w_{0}$. Also, a forward-looking individual should always choose (2) over 3(iii) since the former augments the pension in period 2 by $r$.

This reduces the effective choice to (1), (2) and 3(i). The outcome will depend on relative utility from leisure and income, the discount rate, the survival probability, and the deferral rate. These last three factors, together with the tax rate if the individual is working, determine whether deferral is actuarially fair. For someone working this requires that $(1-t)=\theta \beta r$. Note that the tax system tends to favour deferral since all of the pension is likely to be taxed if the individual receives it now in addition to his earnings, but no tax will be paid on the additional income received in retirement.

It is possible to distinguish four types of people.

- Type $1 \mathrm{~s}$ retire and start drawing their pension immediately. They tend to derive high utility from leisure relative to additional income and deferral is more likely to be actuarially unfavourable.

- Type 2 s choose to work and earn at or less than the earnings test limit and start drawing their pension immediately. For them deferral is likely to be actuarially unfavourable and they would derive relatively lower utility from any increased income they could get earning more the earnings rule threshold.

- Type $3 \mathrm{~s}$ are those who work and defer pension and for whom deferral is actuarially favourable.

- Type $4 \mathrm{~s}$ are those who work and defer and for whom deferral is actuarially 
unfavourable, but who derive high utility from income relative to leisure and are therefore prepared to pay the tax implicit in deferring. Note, however, that the penalty they pay for earning above the earnings rule threshold is less than if there were no deferral option when they would lose $\theta \beta p r$ in the second period.

If the earnings rule is abolished, (3) becomes;

$$
\text { (3') } \quad Y=(w+p)(1-t)+\theta \beta p
$$

How does this affect the four types? Type 1s and type $3 \mathrm{~s}$ will be unaffected. Type $2 \mathrm{~s}$ will tend to work more following the abolition of the earnings rule. They will have an incentive to increase their hours and earnings since $\partial Y / \partial w>0$. Type $4 \mathrm{~s}$, for whom deferral is actuarially unfavourable, will no longer have to defer if the earnings rule is abolished. They will experience a positive income effect and could choose to reduce the number of hours worked as a result.

A priori the impact of abolishing the earnings rule on work incentives is ambiguous. It depends on the relative numbers of people of type 2 and type 4 , and on the size of the implicit tax rate facing type $4 \mathrm{~s}$ who chose to defer when the earnings rule was in place. When the government announced the abolition of the earnings rule it claimed that more than 400,000 people over pensionable age would gain as a result (see Whitehouse (1991)). This total included 200,000 people who would choose to work and earn more and 200,000 who would gain because they would no longer have to defer their pension. Taken literally, these government figures imply a fairly equal split between people of type 2 , who would work more following the abolition of the earnings rule, and people of type 4 who were previously deferring at an actuarially unfair rate and who might choose to work less after the abolition of the earnings 
rule. In fact this 200,000 figure for the number of people who would gain from no longer having to defer their pension seems too high since it is close to the total number of deferrers and will therefore include some people of type 3.

Given their longer life expectancy, women are more likely than men to be type 3s. This suggests that the abolition of the earnings rule might have had a differential impact across the genders. In practice, however, the majority of women would not have been directly affected by the reform since they had chosen to opt out of the state pension system altogether. But they may have been indirectly affected by the reform through its effect on their spouses' behaviour. There are three possible cases. The first case is women married to type 2 men, i.e. men who are likely to increase their hours as a result of the earnings rule being abolished. This will cause a positive income effect for the wife who, if she is working, is likely to reduce her hours - or stop working altogether. The second and third cases are both women married to type 4 men, i.e. those for whom deferral is actuarially unfair and who choose to start drawing their pension once the earnings rule is abolished. The distinction lies in whether the husbands take account of the lifetime of the couple in assessing whether deferral would be actuarially unfair, or only their own lifetimes. If the former, then abolishing the earnings rule and allowing the husband to draw the pension immediately will have a positive income effect for both spouses. If the latter, then there may be some wives who experience a fall in their total incomes following the abolition of the earnings rule if their husbands choose not to defer. For members of this third group the abolition of the earnings rule has a negative income effect which could cause them to increase their hours of work. If they do not, then abolition of the earnings rule could in the longer term, generate higher levels of poverty among elderly widows. 


\section{The effect of abolishing the earnings rule}

To evaluate the effect of abolishing the earnings rule we compare the change in hours and earnings of men aged 65-69 and women aged 60-64 before and after the reform with the change in the same variables over the same period of two comparison groups. The first consists of men and women five years before state pension age (i.e. men aged 60-64 and women aged 55-59) who remained ineligible for the state pension throughout. The second consists of older men aged 70-74 and women aged 65-69 who could receive the state pension without being subject to earnings rule throughout. The purpose of the comparison groups is to control for the potential effect of macrofactors as well as other policy measures that might have affected hours and earnings before and after the reform. ${ }^{7}$

To identify the effect of the reform from such a differences-in-differences approach two conditions must be satisfied. ${ }^{8}$ First, the composition of the groups must be stable across time and second, the control and treatment group must be subject to (and react in the same way to) macro trends. The first condition is potentially violated if there are any spillover effects from the reform to the control groups. This is an issue for members of the younger control group who might change their labour market behaviour in anticipation of no longer having to face the earnings rule when they reach state pension age. A second potential problem with the younger control group is that the balance between full-time and part-time workers is quite different in the

\footnotetext{
${ }^{7}$ It is worth pointing out that the biggest work incentive effects for older workers are likely to be generated by occupational pension schemes. However, we should capture any changes in the incentives generated by these schemes by including the younger and older control groups.
} 
younger male cohort compared to the treatment group and is much more similar in the treatment group and the older cohort. Since full-time and part-time workers might be differentially affected by macro factors, this also will tend to make the younger cohort a less valid control. Nevertheless because of relatively small sample sizes for the older control group, we present results including the younger control group for comparison.

\section{Data}

The data are taken from the Family Expenditure Survey from April 1984 - March 1994. The FES contains reliable and consistent information on employment status, hours worked and earnings that will allow us to look at employment before and after the abolition of the earnings rule. Also, the FES contains information on individuals' state pension income that will allow us to make some assessment of the extent to which individuals defer pension receipt. Table 3 shows the sample sizes for the 'treatment' group and the two 'control' groups. Among the older age groups participation rates are very low and pooling across a number of years is necessary to increase sample sizes when looking at hours and earnings.

Table 3 Sample sizes

\begin{tabular}{|l|l|ll|ll|}
\hline & & Pre-reform & Post-reform & \\
& & All & Employed & All & Employed \\
\hline Treatment & Men aged 65-69 & 2111 & 160 & 1713 & 128 \\
Control 1 & Men aged 60-64 & 2185 & 888 & 1558 & 511 \\
Control 2 & Men aged 70-74 & 1573 & 77 & 1371 & 67 \\
\hline Treatment & Women aged 60-64 & 2697 & 450 & 1916 & 338 \\
Control 1 & Women aged 55-59 & 2399 & 1125 & 1718 & 838 \\
Control 2 & Women aged 65-69 & 2576 & 134 & 2017 & 119 \\
\hline
\end{tabular}

\footnotetext{
${ }^{8}$ See Brian Bell, Richard Blundell and John Van Reenen (1999) for an excellent discussion of the issues.
} 


\section{Pre-reform}

The earnings rule as it operated in the UK contained a number of potential ambiguities. For example, it combined an hours rule with an earnings rule and it allowed for people whose earnings were 'occasionally greater' than the earnings rule limits to receive a full basic state pension. Also, work-related costs could be taken into consideration when defining relevant earnings, including for example the cost of dry-cleaning clothes used for work. All these factors could make the earnings rule a less than binding constraint in practice - and also make it harder to identify an effect from its abolition.

Table 4 provides evidence on how binding the earnings rule was in practice. It shows the proportion of men in receipt of state pension income at least as great as the basic state pension. It shows that the earnings threshold was more binding than the limit on hours - a far smaller proportion of men who earned more than the earnings rule threshold received state pension income equal to the full basic state pension than of men who worked more than twelve hours. However, more than one-fifth of men earning more than the earnings limit did receive as much state pension income as the full basic state pension, although this proportion falls once we allow for weekly workrelated costs of $£ 5, £ 10$ and $£ 20$. This may reflect receipt of income in the form of the secondary state pension, SERPS, which was not subject to the earnings limit and which can not be separated from total state pension income in the FES. 
Table 4 Proportion of men receiving the full basic state pension

\begin{tabular}{|l|c|}
\hline Men aged 65-69 & Pre-reform \\
\hline Hours rule & \\
Worked < 12 hours a week & 0.9348 \\
Worked >= 12 hours a week & 0.6934 \\
\hline Earnings rule & \\
Earned < upper limit & 0.9549 \\
Earned > upper limit & 0.2200 \\
Earned > (upper limit $+£ 5)$ & 0.1702 \\
Earned > (upper limit $+£ 10)$ & 0.1333 \\
Earned > (upper limit $+£ 20)$ & 0.1250 \\
\hline
\end{tabular}

Figure 1 plots the distribution of earnings for men aged 65-69 and women aged 60-64 when the earnings rule was in place. We focus on the period after April 1986 since from this time the earnings rule thresholds were unchanged (see Table 2). The earnings rule did appear to have had some impact on earnings for men and women. The allowance for work-related costs in the earnings rule, but not our definition of earnings, will tend to have a smoothing effect on any potential 'kink' in the distribution of earnings at the threshold. Even so, there is some bunching in the distribution of male and female earnings around the $£ 75$ threshold, although in neither case is the mass of the distribution to be found around these points. The largest spikes in the distributions of male and female earnings occur around $£ 40$ a week, reflecting the Lower Earnings Limit for National Insurance contributions. ${ }^{9}$

\section{$<<$ Figure 1 near here $>>$}

\footnotetext{
${ }^{9}$ Although men and women over the state pension do not have to pay employee's National Insurance contributions, the fact that employers are liable for employer's NI means that the LEL is still important even after state pension ages.
} 


\section{Post-reform}

Table 5 summarizes participation rates and average hours for the treatment and control groups before and after abolition of the earnings rule. The only significant change in participation occurs for the younger men. The fall in employment among this group - and the likely effect of this on the composition of the sample of workers in this age range - poses further potential problems for using younger workers as a control group in looking at hours and earnings.

The evidence suggests that the abolition of the earnings rule had a significant effect on the number of hours worked by men in the treatment group. A Wilcoxon rank-sum test rejects the null that the two distributions are independent samples from populations with the same distribution. Also, the average number of hours worked by men in the treatment group increased significantly, by nearly four hours per worker compared to no significant change in average hours, or in the distribution of hours, among the older or younger cohort over the same period.

Table 5 Participation and hours, before and after the reform

\begin{tabular}{|l|ll|ll|l|}
\hline & \multicolumn{2}{|l|}{ Participation (\%) } & \multicolumn{2}{l|}{ Mean hours (>0) } & \multicolumn{2}{l|}{ Rank sum } \\
& Pre & Post & Pre & Post & test (hours) \\
\hline Men 65-69 & 7.58 & 7.47 & 22.43 & $26.27 * *$ & 2.266 \\
Men 60-64 & 40.64 & $32.80 * *$ & 40.62 & 40.35 & 0.560 \\
Men 70-74 & 4.90 & 4.89 & 17.81 & 18.40 & 1.041 \\
\hline Women 60-64 & 16.39 & 17.64 & 21.06 & $22.89 *$ & 1.611 \\
Women 55-59 & 46.89 & 48.78 & 27.09 & 27.06 & 0.407 \\
Women 65-69 & 5.20 & 5.90 & 15.32 & 16.59 & 0.802 \\
\hline
\end{tabular}

** change significant at $5 \%$ level; * change significant at the $10 \%$ level

This is confirmed by regression analysis. We regress weekly hours for individuals in the three groups on a set of dummies for the treatment and younger control groups 
and a dummy for the period after the abolition of the earnings test. We include an interaction term that takes the value one for the treatment group in the post-reform period to pick up any differential change in the hours of the treatment group after the reform relative to the two control groups. We control for education, marital status, presence of children in the household and spouse's age, employment and education. The results are summarised in the first column of Table 6. With two control groups, we find a significant increase in the average number of weekly hours - around four hours a week - among the treatment group after the reform. Excluding the younger control group there is still an increase of around three hours per week, but the smaller sample size increases the standard error.

Table 6 Regression results (men)

\begin{tabular}{|c|c|c|c|c|c|c|}
\hline \multirow[b]{2}{*}{ Control groups } & \multicolumn{2}{|c|}{$\begin{array}{l}\text { OLS - hours worked per } \\
\text { week }\end{array}$} & \multicolumn{2}{|c|}{$\begin{array}{l}\text { Probit - worked more } \\
\text { than } 40 \text { hrs }\end{array}$} & \multicolumn{2}{|c|}{ OLS - weekly earnings } \\
\hline & $\begin{array}{l}\text { Older and } \\
\text { younger }\end{array}$ & Older only & $\begin{array}{l}\text { Older and } \\
\text { younger }\end{array}$ & Older only & $\begin{array}{l}\text { Older and } \\
\text { younger }\end{array}$ & Older only \\
\hline $\begin{array}{l}\text { Treatment } \\
\text { group }\end{array}$ & $\begin{array}{l}4.119 \\
(1.337)\end{array}$ & $\begin{array}{l}3.894 \\
(1.907)\end{array}$ & $\begin{array}{l}0.208 \\
(0.082)\end{array}$ & $\begin{array}{l}0.080 \\
(0.047)\end{array}$ & $\begin{array}{l}19.37 \\
(14.12)\end{array}$ & $\begin{array}{l}17.00 \\
(13.45)\end{array}$ \\
\hline $\begin{array}{l}\text { Younger } \\
\text { control }\end{array}$ & $\begin{array}{l}22.249 \\
(1.000)\end{array}$ & - & $\begin{array}{l}0.488 \\
(0.033)\end{array}$ & - & $\begin{array}{l}135.85 \\
(10.50)\end{array}$ & - \\
\hline $\begin{array}{l}\text { Post-reform } \\
\text { dummy }\end{array}$ & $\begin{array}{l}-0.297 \\
(0.612)\end{array}$ & $\begin{array}{l}0.778 \\
(2.269)\end{array}$ & $\begin{array}{l}-0.018 \\
(0.027)\end{array}$ & $\begin{array}{l}-0.035 \\
(0.076)\end{array}$ & $\begin{array}{l}-2.74 \\
(6.27)\end{array}$ & $\begin{array}{l}-7.77 \\
(16.23)\end{array}$ \\
\hline $\begin{array}{l}\text { Treatment* } \\
\text { Dummy }\end{array}$ & $\begin{array}{l}4.153 \\
(1.478) \\
\end{array}$ & $\begin{array}{l}3.130 \\
(2.790)\end{array}$ & $\begin{array}{l}0.227 \\
(0.066)\end{array}$ & $\begin{array}{l}0.176 \\
(0.113)\end{array}$ & $\begin{array}{l}25.73 \\
(15.77)\end{array}$ & $\begin{array}{l}32.87 \\
(20.16)\end{array}$ \\
\hline No. obs & 1831 & 432 & 1831 & 432 & 1831 & 432 \\
\hline R-squared & 0.3381 & 0.0991 & & & 0.1960 & 0.1643 \\
\hline Log likelihood & & & -1108.9 & -161.7 & & \\
\hline \multicolumn{7}{|c|}{$\begin{array}{l}\text { These regressions control for education, marital status, presence of children in the household, spouse's } \\
\text { age, employment and education }\end{array}$} \\
\hline
\end{tabular}

Table 6 also shows the marginal effects from a probit regression on whether or not the individual works 40 or more hours a week. There is a significant increase in the 
proportion of men in the treatment group working more than 40 hours a week after the reform even compared against the older control group only. This is consistent with the predictions of Zabalza et al (1980) of a shift from part-time to full-time employment following the abolition of the earnings rule. The final column of Table 6 summarises the results of a regression of earnings on the same variables and shows a positive and significant increase in the earnings of the treatment group after the reform compared to the control groups.

Table 7 Regression results (women)

\begin{tabular}{|c|c|c|c|c|c|c|}
\hline \multirow{2}{*}{\begin{tabular}{|l|} 
Control groups \\
\end{tabular}} & \multicolumn{2}{|c|}{$\begin{array}{l}\text { OLS-hours worked per } \\
\text { week }\end{array}$} & \multicolumn{2}{|c|}{$\begin{array}{l}\text { Probit-worked more } \\
\text { than } 30 \text { hrs }\end{array}$} & \multicolumn{2}{|c|}{ OLS - weekly earnings } \\
\hline & $\begin{array}{l}\text { Older and } \\
\text { younger }\end{array}$ & Older only & $\begin{array}{l}\text { Older and } \\
\text { younger }\end{array}$ & Older only & $\begin{array}{l}\text { Older and } \\
\text { younger }\end{array}$ & Older only \\
\hline $\begin{array}{l}\text { Treatment } \\
\text { group }\end{array}$ & $\begin{array}{l}5.214 \\
(1.028)\end{array}$ & $\begin{array}{l}6.288 \\
1.272)\end{array}$ & $\begin{array}{l}0.172 \\
(0.048)\end{array}$ & $\begin{array}{l}0.171 \\
(0.040)\end{array}$ & $\begin{array}{l}26.83 \\
(5.28)\end{array}$ & $\begin{array}{l}28.93 \\
(6.08)\end{array}$ \\
\hline Younger control & $\begin{array}{l}11.460 \\
(0.861)\end{array}$ & - & $\begin{array}{l}0.372 \\
(0.033)\end{array}$ & - & $\begin{array}{l}54.53 \\
(4.39)\end{array}$ & - \\
\hline $\begin{array}{l}\text { Post-reform } \\
\text { dummy }\end{array}$ & $\begin{array}{l}-0.186 \\
(0.585)\end{array}$ & $\begin{array}{l}2.070 \\
(1.605)\end{array}$ & $\begin{array}{l}-0.029 \\
(0.024)\end{array}$ & $\begin{array}{l}0.070 \\
(0.065)\end{array}$ & $\begin{array}{l}-10.43 \\
(2.72)\end{array}$ & $\begin{array}{l}-3.33 \\
(7.84)\end{array}$ \\
\hline $\begin{array}{l}\text { Treatment* } \\
\text { Dummy }\end{array}$ & $\begin{array}{l}2.350 \\
(1.084)\end{array}$ & $\begin{array}{l}-0.298 \\
(1.858)\end{array}$ & $\begin{array}{l}0.103 \\
(0.046)\end{array}$ & $\begin{array}{l}\mathbf{0 . 0 1 8} \\
(0.071)\end{array}$ & $\begin{array}{l}9.46 \\
(5.37)\end{array}$ & $\begin{array}{l}1.69 \\
(8.99)\end{array}$ \\
\hline No. obs & 2694 & 984 & 2694 & 984 & 2694 & 984 \\
\hline R-squared & .1205 & .0600 & & & 0.1472 & 0.1125 \\
\hline Log likelihood & & & -1681.54 & -546.48 & & \\
\hline \multicolumn{7}{|c|}{$\begin{array}{l}\text { These regressions control for education, marital status, presence of children in the household, spouse's } \\
\text { age, employment and education }\end{array}$} \\
\hline
\end{tabular}

The results for women are less conclusive. A Wilcoxon rank-sum test fails to reject that the distributions of hours are the same before and after the reform, but there is an increase in the average number of hours worked among the treatment group which is significant at the 10 per cent level (see Table 5). The results of regression analysis (reported in Table 7) show an increase in average weekly hours for the treatment 
group in the post-reform period, compared to the younger and older control groups. But the coefficient disappears once we omit the younger control group. There is also no significant increase in the proportion of women in the treatment group working thirty hours or more a week ${ }^{10}$ compared to the older control and no significant change in earnings. The fact that the results for women are inconclusive may reflect the fact that the majority of married women are only indirectly affected by the abolition of the earnings rule. Small sample sizes mean that we are unable to perform separate regressions for married and single women.

\section{Deferral}

There is little evidence of any reduction in employment that might have been caused by the positive wealth effect for people of type 4 (i.e. those who previously chose to work and defer at an actuarially unfair rate). One possible explanation is that for most people who chose to defer their pension, deferral was actuarially favourable. In this case, however, we would not expect to see a large fall in the number of people who choose to defer after the reform. Figure 2 provides some evidence to support this. It shows cohort profiles of the proportion of men who received increments to their pension as a result of deferral from the official statistics. The cohorts are defined according to the year in which people reach the state pension age. The oldest is those who reached 65 in 1980. At younger ages, the cohort profiles rise. This reflects increasing numbers of people who retire after the state pension age and begin to receive their deferred pension. The increase in observed deferrals at older ages is likely to reflect the effects of differential mortality. There is a gradual decline in

\footnotetext{
${ }^{10}$ We choose this lower threshold since so few women work 40 hours a week or more.
} 
deferral across successive cohorts, but no evidence of a structural break after the abolition of the earnings test.

\section{$<<$ Figure 2 near here $>>$}

\section{Conclusions}

A simple differences in differences analysis shows that the abolition had a positive effect on the hours and earnings of men, although the evidence for women is inconclusive. Among men in the affected age range there was an increase of between $3-4$ hours per week. To get some idea of the magnitude of this effect, an earnings response of this size would generate additional tax revenue for the government of around $£ 20$ million per year (in 1989 prices).

There is no evidence of any reduction in hours that would arise as a result of a positive wealth effect from abolishing the earnings test. One possible explanation is that for most of those who chose to defer deferral was actuarially fair. Support for this hypothesis comes from the fact that there is little indication of a significant reduction in deferral after the earnings test was abolished. 


\section{References}

Brian Bell, Richard Blundell and John Van Reenen, (1999) 'Getting the unemployed back to work: the role of targeted wage subsidies', International Tax and Public Finance 6, 339-60.

Leora Friedberg (1997) The labor supply effects of the social security earnings test, University of California mimeo

Jon Gruber and Peter Orszag (1999) The social security earnings test; an overview and examination of reform options, paper presented at the first annual joint conference for the retirement research consortium, May 1999

Richard Smith and Mark Rowland (1986) Rights guide to non-means-tested social security benefits London: Child Povery Action Group

Edward Whitehouse (1990) 'The abolition of the pensions 'earnings rule'” Fiscal Studies 11(3), 55-70

Zabalza, A., Chris Pissarides, and M. Barton (1980) 'Social Security and the Choice Between Full-Time Work, Part-Time Work, and Retirement' Journal of Public Economics 14, 245-276. 
Figure 1 Pre-reform distribution of weekly earnings

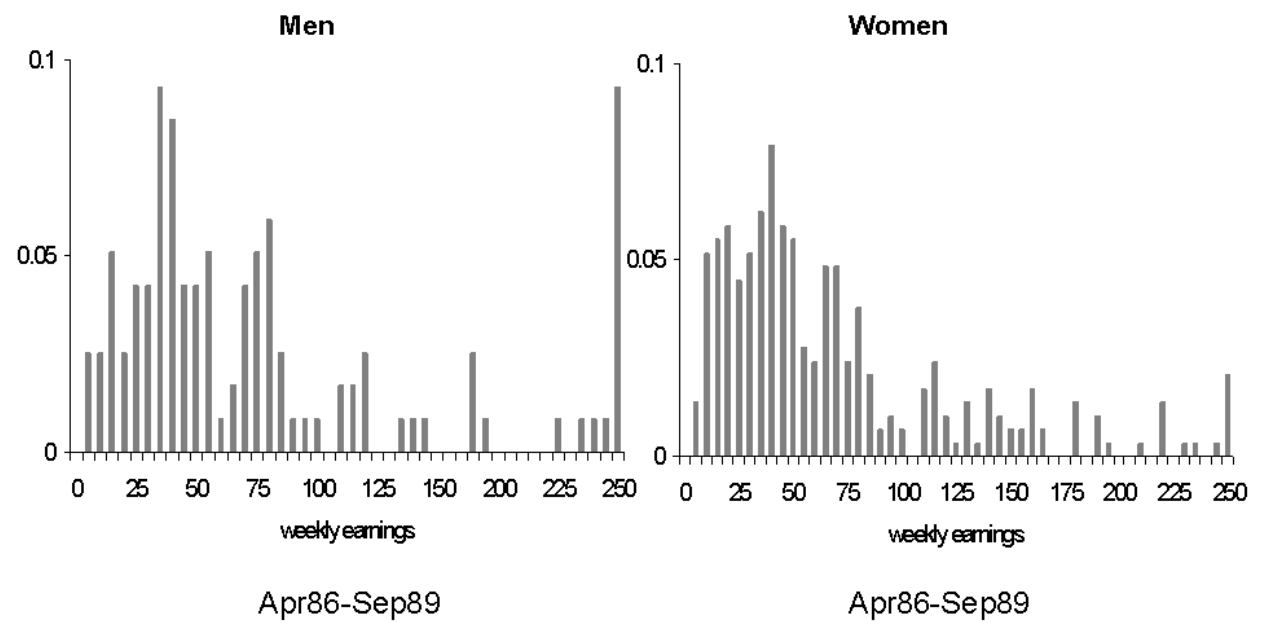

Figure $2 \%$ Men in receipt of deferred pension, by cohort

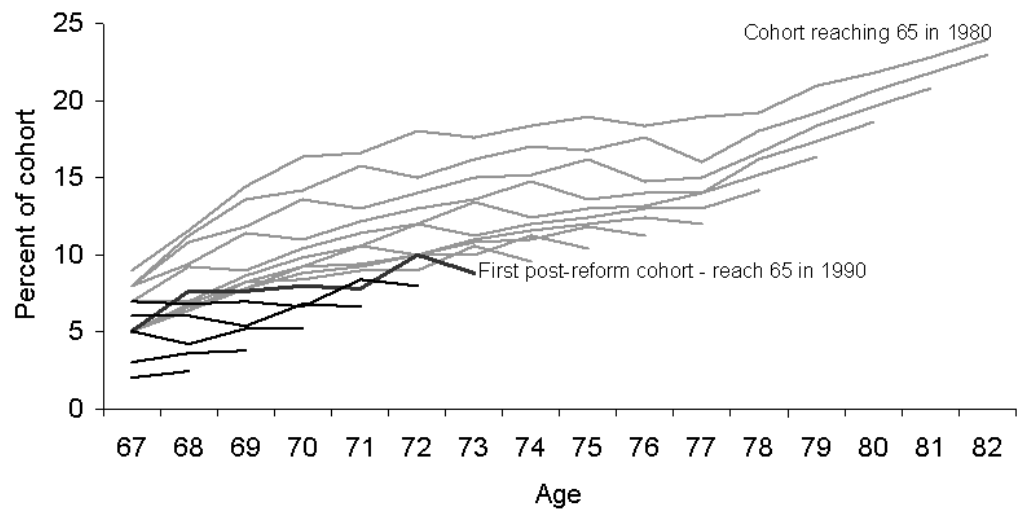

